\title{
HUBUNGAN ANTARA KEMAMPUAN REPRODUKSI, KEPEMILIKAN ANAK, TEMPAT TINGGAL, PENDIDIKAN DAN STATUS BEKERJA PADA WANITA SUDAH MENIKAH DENGAN PEMAKAIAN KONTRASEPSI HORMONAL DI INDONESIA TAHUN 2017

\author{
Relationships among Reproductive Ability, Child Ownership, Housing, \\ Contraception in Indonesia in 2017
} Education and Working Status for Married Women with the of Hormonal
}

\author{
1Diyah Herowati, ${ }^{2}$ Mugeni Sugiharto \\ BKKBN Propinsi Jawa Timur, ${ }^{1}$ Pusat Penelitian dan Pengembangan Humaniora dan Manajemen Kesehatan ${ }^{2}$ \\ Naskah masuk: 10 Januari 2018 Perbaikan: 17 Januari 2018 Layak terbit: 5 Maret 2019 \\ http://dx.doi.org/10.22435/hsr.v22i2.1553
}

\begin{abstract}
ABSTRAK
Kontrasepsi hormonal, seperti suntik, pil dan implant adalah jenis alat kontrasepsi yang di gunakan oleh wanita yang sudah menikah di Indonesia, karena sangat efektif mencegah kehamilan dan mudah penggunaannya, namun memiliki efek samping yang berbeda. Penelitian ini bertujuan untuk menganalisis hubungan antara kemampuan reproduksi, kepemilikan anak, tempat tinggal, pendidikan dan status bekerja pada wanita sudah menikah dengan penggunaan alat kontrasepsi hormonal. Jenis penelitian kuantitatif menggunakan data SDKI tahun 2017 yang di analisis dengan uji korelasi bivariat dan deskriptif ditampilkan dalam bentuk tabel. Analisis menunjukkan, bahwa terdapat hubungan signifikan antara kemampuan reproduksi, lokasi tempat tinggal, kepemilikan jumlah anak dan pekerjaan wanita menikah dengan penggunaan kontrasepsi hormonal, akan tetapi variabel pendidikan tidak ada hubungan. Kontrasepsi hormonal disimpulkan sebagai jenis kontrasepsi yang efektif mencegah kehamilan. Wanita menikah lebih banyak menggunakan kontrasepsi suntik, kemudian pil dan implant. Wanita menikah disarankan untuk menggunakan kontrasepsi suntik, karena efektif mencegah kehamilan, efek samping yang ringan dan mudah penggunaannya, tetapi perlu memperoleh informasi yang benar terlebih dahulu dari petugas kesehatan.
\end{abstract}

Kata kunci: Kontrasepsi hormonal, Kesehatan, Efek samping, Efektif.

\begin{abstract}
Hormonal contraception type such as: injections, pills and implants is a type of contraception used by married women in Indonesia, because the contraception is very effective for preventing pregnancy and very easy to use. Nevertheless, each type has different side effects. This study is to analyse the relationship between reproductive ability, child ownership, residence, education and work status for married women with hormonal contraceptive use. This quantitative study obtained the data from the Indonesian Demographic Health Survey 2017 which was analyzed by bivariate correlation tests and displayed descriptively in a table form. The results indicated significant among reproductive capacity, location of residence, ownership of the number of children and employment of married women with hormonal contraception use. However the education variable had no relationship. Hormonal contraception type was concluded as a type of contraception that effectively prevents pregnancy. Married women used more injectable contraception, then pills and implants. They are advised to use injectable contraception as it effectively prevents pregnancies, reduces side effects, and is easy to use. Thus, they have to gain correct information first from health workers.
\end{abstract}

Keywords: Hormonal contraception, health, side effects, effective

Korespondensi:

Diyah Herowati

BKKBN Propinsi Jawa Timur

E-mail: dherowati@gmail.com 


\section{PENDAHULUAN}

Laju pertumbuhan penduduk Indonesia dalam Rencana Pembangunan Jangka Menengah Nasional (RPJMN) 2015-2019 meningkat sebesar 1,49\% per tahun, hal ini menjadi permasalahan kependudukan dan pembangunan bangsa Indonesia (Zahroh and Isfandiari, 2015). Upaya pemerintah untuk mengendalikan pertumbuhan penduduk dilakukan melalui program keluarga berencana (Bernadus et al., 2013). Salah satu kebijakan program KB adalah memberikan pelayanan kontrasepsi yang dapat dipertanggungjawabkan dari segi agama, norma budaya, etika serta kesehatan sesuai amanat Permenkes No. 97 tahun 2014 tentang Pelayanan kesehatan masa sebelum hamil, masa hamil, persalinan dan masa sesudah melahirkan, penyelenggaraan pelayanan kontrasepsi, serta pelayanan kesehatan seksual. Kebijakan pemerintah mewajibkan kesertaan ber KB bagi pasangan usia subur (PUS) di setiap keluarga di Indonesia adalah dilandasi upaya untuk mewujudkan keluarga sehat seperti yang diamanatkan dalam Permenkes No. 39 tahun 2016 tentang Pedoman Penyelenggaraan Program Indonesia Sehat dengan Pendekatan Keluarga (PIS PK).

Kontrasepsi KB merupakan metode yang dianjurkan pemerintah untuk mencegah terjadinya kehamilan. Untuk memperoleh hasil yang baik diperlukan kontrasepsi yang berkualitas, agar dapat meningkatkan kesehatan reproduksi dan kesehatan seksual penggunanya (Handayani et al., 2012). Penggunaan kontrasepsi KB salah satunya jenis KB hormonal. KB hormonal lebih diminati PUS, karena menurut Hartanto (2002) dalam Pratiwi et al., (2014), bahwa KB hormonal terbukti mampu mencegah kehamilan dengan tingkat kegagalan $0,25 \%$ dan mudah penggunaannya. Kemudahan penggunaan kontrasepsi hormonal juga menyebabkan diminati wanita yang tinggal di perdesaan dan daerah terpencil (Zahroh and Isfandiari. 2015; (Sari Novalia. 2015; Amran dan Damayanti. 2018). Menurut Manurung (2013), wanita yang berpendidikan lebih tinggi lebih mengetahui jenis kontrasepsi hormonal yang bisa digunakan untuk mencegah kehamilan, sementara hasil penelitian Marlina (2017) dan Andriana dan Amami (2018), ada beberapa faktor yang diduga memiliki kontribusi didalam penggunaan kontrasepsi hormonal jenis implant, antara lain, umur, paritas (jumlah anak yang dilahirkan)), jarak kehamilan, pendidikan, pekerjaan, biaya, jarak ke tempat pelayanan kesehatan, dan dukungan suami.
Jenis metode kontrasepsi hormonal atau metode jangka pendek menurut Hernawatiaj (2008) dalam Sriwahyuni dan Wahyuni, (2012) dan Sari Novalia (2015) ada tiga jenis yaitu injeksi (suntik), pil dan implant atau susuk yang ditanam untuk periode tertentu. Setiap metode kontrasepsi sangat bermanfaat untuk membantu keluarga dalam mengatur jarak kelahiran dan mencegah kehamilan yang tidak diinginkan atau membatasi jumlah anak sesuai yang diinginkan, namun disisi lain setiap metode kontrasepsi selalu ada efek samping yang harus diperhatikan setiap calon akseptor. Calon akseptor KB perlu berkonsultasi dengan petugas kesehatan terlebih dahulu, sebelum memutuskan jenis metode KB hormonal yang akan digunakan (Pratiwi et al., 2014 ; Sari Novalia, 2015; Sumantri, 2018).

Perbedaan efek samping setiap jenis kontrasepsi menyebabkan setiap WUS menikah memiliki pilihan yang berbeda terhadap masing-masing jenis kontrasepsi hormonal yang diinginkan. Menurut data SDKI Tahun 2012, ada perbedaan penggunaan kontrasepsi hormonal pada wanita menikah yaitu penggunaan injeksi (suntik) pada wanita menikah mencapai $98,0 \%$ lebih tinggi dari PIL $97,3 \%$ dan implant $89,0 \%$. Atas dasar uraian diatas, maka penting untuk dilakukan penelitian hubungan antara kemampuan reproduksi, tingkat pendidikan, jumlah anak dan tempat tinggal pada wanita yang sudah menikah dengan pemakaian jenis kontrasepsi hormonal. Tujuan penelitian ini adalah untuk menganalisis hubungan antara kemampuan reproduksi, kepemilikan anak, tempat tinggal, pendidikan dan status bekerja pada wanita sudah menikah dengan penggunaan alat kontrasepsi hormonal.

\section{METODE}

Penelitian ini termasuk jenis penelitian kuantitatif, dengan desain studi cross sectional. dan menggunakan data Survey Demografi Kesehatan Indonesia (SDKI) tahun 2017. Populasi adalah seluruh akseptor KB yang terdapat di dalam responden SDKI tahun 2017, sedangkan sampel adalah wanita usia subur yang sudah menikah usia 15-49 tahu. Variabel Independent jenis KB hormonal dan variabel dependen karakteristik akseptor KB hormonal, seperti umur, tingkat pendidikan, jumlah anak yang dimiliki responden, lokasi tempat tinggal dan kekayaan. 
Tabel 1. Definisi Operasional Variabel

\begin{tabular}{|c|c|}
\hline Variabel & Defensis operasional \\
\hline Kontrasepsi Hormonal & $\begin{array}{l}\text { Kontrasepsi hormonal menurut hermawatiaj (2008) dalam Efi Sriwahyuni E; Chatarina U } \\
\text { Wahyuni (2012) adalah alat atau obat kontrasepsi yang bertujuan untuk mencegah terjadinya } \\
\text { kehamilan dengan menggunakan bahan baku preparat estrogen dan progesteron yang } \\
\text { jenisnya dibagi } 3 \text { yaitu pil, suntikan dan implant (susuk) }\end{array}$ \\
\hline Wanita menikah & $\begin{array}{l}\text { Menurut SDKI } 2017 \text { disebut married status atau status menikah pada wanita usia subur yang } \\
\text { sudah berusia antara 15-49 tahun }\end{array}$ \\
\hline Umur & $\begin{array}{l}\text { Umur wanita menurut Siswosudarmo dkk (2007) bermanfaat untuk menentukan jenis } \\
\text { kemampuan reproduksi, jika umur }<20 \text { tahun disebut reproduksi muda, umur } 20-35 \text { tahun } \\
\text { disebut reproduksi sehat atau disebut juga fase menjarangkan kelahiran dan umur } 36-45 \\
\text { tahun disebut reproduksi tua atau fase hamil berisiko tinggi. }\end{array}$ \\
\hline Pendidikan ibu & $\begin{array}{l}\text { Pendidikan ibu dalam SDKI } 2017 \text { disebut Mother's education yaitu pendidikan terakhir yang } \\
\text { ditandai kepemilikan ijazah. Ada } 5 \text { kelompok education yaitu no education (tidak sekolah), } \\
\text { some primary (tidak tamat SD), completed primary (tamat SD), some secondary (tidak tamat } \\
\text { SMP), completed secondary (tamat SMP) dan more than secondary (SMA dan perguruan } \\
\text { tinggi) }\end{array}$ \\
\hline Tempat tinggal & $\begin{array}{l}\text { Menurut SDKI 2017, tempat tinggal disebut residence di bagi dalam } 2 \text { kategori yaitu rural } \\
\text { (perdesaan) dan urban (perkotaan), sesuai ketentuan Administratif yang ada di wilayah itu }\end{array}$ \\
\hline Kepemilikan Anak & $\begin{array}{l}\text { Menurut Schoemaker, } 2005 \text { dibagi empat kategori yaitu jumlah anak 1-2 dalam keluarga } \\
\text { disebut jumlah anak ideal, jumlah } 3 \text { anak yang dimiliki keluarga disebut cukup dan jika } \\
\text { memiliki 4-5 anak disebut banyak anak, dan jika memiliki } \geq 6 \text { termasuk sangat banyak anak }\end{array}$ \\
\hline
\end{tabular}

Berikut adalah uraian definisi operasional variabel yang akan dianalisis :

Analisis data dilakukan secara deskriptif dengan analisis tabel dan dilanjutkan analisis untuk mengetahui ada tidaknya hubungan antar variabel, dengan menggunakan korelasi bivariat pearson (Ujiani, 2005), Confident Interval (Cl) atau tingkat kepercayaan $95 \%$ dan tingkat kesalahan (a) 5\%. Syarat ada hubungan antara variabel adalah apabila hasil analisis korelasi menunjukkan nilai Sig (2 tailed) atau nilai $\mathrm{P}<\alpha=5 \%$, hal ini menunjukkan Ho di tolak dan $\mathrm{H} 1$ di terima, artinya ada hubungan antar variabel yang dianalisis.

\section{HASIL}

Hasil analisis deskriptif dat SDKI 2017, menunjukkan, bahwa pemakaian kontrasepsi hormonal pada WUS yang sudah menikah sebanyak 15005 , terbanyak adalah jenis suntik sebanyak $64,2 \%$ (9639 orang), disusul jenis implant sebanyak 10,4\% (1555 orang) dan terendah adalah jenis PIL sebanyak 2,4\% (3811 orang). Berikut data karakteristik wanita usia subur yang sudah menikah yang menggunakan kontrasepsi hormonal dan hasil uji korelasi.

Analisis kemampuan reproduksi WUS menikah dengan pemanfaatan kontrasepsi hormonal secara deskriptif menunjukkan, bahwa jenis reproduksi muda (usia 15-19 tahun) lebih banyak menggunakan suntik 78\% (231 orang) dan terendah menggunakan implant
5\% (5 orang), sementara reproduksi sehat usia 20-35 tahun lebih banyak menggunakan suntik 69\% (5891 orang) dan terendah menggunakan implant 10\% (825 orang) dan pada reproduksi tua usia 36-45 tahun juga lebih tinggi menggunakan suntik 57\% (3517 orang) dan terendah menggunakan implant $12 \%$ (715 orang).

Faktor lokasi tempat tinggal WUS menikah juga ikut berpengaruh terhadap pemanfaatan kontrasepsi hormonal yang digunakan oleh WUS menikah. Penggunaan KB hormonal suntik lebih tinggi pada WUS yang tinggal di perdesaan 38\% (5649 wanita) di banding di perkotaan 27\% (3990 orang).

Penggunaan PIL juga lebih tinggi wanita yang tinggal di perdesaan 13\% (1989 orang) di banding di perkotaan $12 \%$ (1822 orang), implant pun lebih tinggi di perdesaan 7\% (1108 orang) di banding yang tinggal di perkotaan $3 \%$ (459 orang). Selain itu yang menggunakan PIL tertinggi terdapat pada WUS dengan pEndidikan tamat SD 8\% (1169 orang) dan terendah pada WUS yang tidak sekolah $0,3 \%$ (44 orang). Penggunaan implant tertinggi terdapat WUS tidak tamat SMP 3,1\% (465 orang), terendah pada WUS yang tidak sekolah 0,1\% (16 orang). Penggunaan kontrasepsi suntik tertinggi terdapat pada WUS tidak tamat SMP 20,4\% (3061 orang) dan terendah terdapat pada WUS yang tidak sekolah 0,6\% (95 orang). Penggunaan kontrasepsi suntik lebih tinggi terdapat pada WUS yang mempunyai anak ideal (sebanyak 1-2 orang anak) 66\% (6780 
Tabel 2. Pemakaian KB Hormonal oleh WUS Sudah Menikah dan Hasil Uji Korelasi, SDKI 2017

\begin{tabular}{|c|c|c|c|c|c|c|}
\hline \multirow{2}{*}{ No } & \multirow{2}{*}{ Uraian } & \multicolumn{3}{|c|}{ Jenis KB Hormonal } & \multicolumn{2}{|c|}{$\begin{array}{l}\text { Hasil uji korelasi } \\
\alpha=5 \% \text { dan } \mathrm{Cl} 95 \%\end{array}$} \\
\hline & & Pil & Implant & Suntik & $P$-value & Keterangan \\
\hline \multirow[t]{4}{*}{1} & Jenis Reproduksi pada WUS & & & & \multirow{4}{*}{0,00} & \multirow{4}{*}{ Terdapat hubungan } \\
\hline & Reproduksi muda usia 15-19 th & 50 & 15 & 231 & & \\
\hline & Reproduksi sehat usia $20-35$ th & 1781 & 825 & 5891 & & \\
\hline & Reproduksi tua usia 36-45 th & 1980 & 715 & 3517 & & \\
\hline \multirow[t]{3}{*}{2} & Tempat tinggal & & & & \multirow{3}{*}{0,00} & \multirow{3}{*}{ Terdapat hubungan } \\
\hline & Perkotaan & 1822 & 447 & 3990 & & \\
\hline & Perdesaan & 1989 & 1108 & 5649 & & \\
\hline \multirow[t]{7}{*}{3} & Pendidikan & & & & \multirow{7}{*}{0,400} & \\
\hline & Tidak sekolah & 44 & 16 & 95 & & \multirow{6}{*}{ Tidak ada hubungan } \\
\hline & Tidak tamat SD & 344 & 180 & 831 & & \\
\hline & Tamat SD & 1169 & 448 & 2851 & & \\
\hline & Tidak tamat SMP & 1094 & 465 & 3061 & & \\
\hline & Tamat SMP & 924 & 340 & 2221 & & \\
\hline & Tamat SMA dan Perguruan Tinggi & 235 & 106 & 580 & & \\
\hline \multirow[t]{5}{*}{4} & Jumlah anak yang dimiliki & & & & & \\
\hline & Jumlah anak ideal ( $\leq 2$ anak) & 2516 & 922 & 6780 & & \\
\hline & Jumlah Cukup anak (3 anak) & 885 & 367 & 1870 & 0,000 & Terdapat hubungan \\
\hline & Banyak anak ( 4-5 anak) & 368 & 206 & 872 & & \\
\hline & Sangat banyak ( $\geq 6$ anak) & 41 & 60 & 118 & & \\
\hline \multirow[t]{3}{*}{6} & Pekerjaan & & & & & \\
\hline & Tidak bekerja & 1502 & 572 & 4291 & 0,008 & Terdapat hubungan \\
\hline & Bekerja & 2309 & 986 & 5345 & & \\
\hline
\end{tabular}

orang) dan terendah pada WUS dengan memiliki anak 6 orang. Penggunaan kontrasepsi pil tertinggi terdapat pada WUS dengan memiliki anak 3 orang sebanyak $28 \%$ (885 orang) dan terendah terdapat pada WUS yang mempunyai anak 6 sebanyak 19\% (41 orang). Penggunaan implant tertinggi pada WUS yang memiliki anak 6 orang sebanyak 27\% (60 orang) dan terendah terdapat pada ibu yang memiliki anak $<2$ sebanyak 9\% (922 orang). Pemilihan kontrasepsi hormonal terkait pekerjaan WUS menikah, maka penggunaan kontrasepsi suntik tertinggi terdapat pada WUS tidak bekerja 67\% (4291 orang) dan penggunaan PIL tertinggi 27\% (2309 orang) terdapat pada WUS yang bekerja.

Analisis korelasi bivariat, dilakukan untuk mengetahui hubungan antara variabel. Variabel yang menunjukkan ada hubungan signifikan dengan pemakaian alat kontrasepsi hormonal adalah kemampuan reproduksi dengan hasil yang signifikan $P=0,00<\alpha(5 \%)$, begitu pula dengan lokasi tempat tinggal WUS juga menunjukkan hubungan signifikan $P=0,00<\alpha(5 \%)$, kepemilikan anak oleh
WUS menikah juga menunjukkan hubungan yang signifikan $\mathrm{P}=0,00<\alpha(5 \%)$, pekerjaan WUS menikah juga menunjukkan ada hubungan signifikan dengan pemilihan pemanfaatan KB hormonal, dengan nilai $P$ $0,00<\alpha(5 \%)$. Variabel yang menunjukkan tidak ada hubungan adalah tingkatan pendidikan, karena hasil analisis $P 0,40>\alpha(5 \%)$.

\section{PEMBAHASAN}

Kebijakan pemerintah, terhadap setiap WUS menikah menggunakan kontrasepsi, ditujukan untuk memberikan kesempatan pada wanita tersebut dalam melakukan pengaturan kelahiran, pembinaan ketahanan keluarga, peningkatan kesejahteraan keluarga kecil, bahagia dan sejahtera, sesuai amanat UU No. 10 tahun 1992, tentang perkembangan kependudukan dan pembangunan keluarga sejahtera. Salah satu metode kontrasepsi yang digunakan adalah kontrasepsi hormonal seperti pil, implant dan suntik. Setiap jenis kontrasepsi memiliki efektivitas dalam mencegah kehamilan, tetapi juga memiliki 
efek samping yang berbeda yang dapat mengganggu kesehatan dan keindahan tubuh, seperti kegemukan atau wajah berjerawat. Akibatnya banyak pengguna kontrasepsi hormonal mengganti alat kontrasepsi yang sudah digunakan ke jenis kontrasepsi yang lain. Saat ini pergantian metode kontrasepsi oleh akseptor dalam 5 tahun terakhir meningkat, yang berganti metode kontrasepsi baru satu kali sebanyak 48 persen dan berganti metode kontrasepsi lebih dari satu kali sebesar 18 persen (Amran dan Damayanti, 2018)

Penggunaan kontrasepsi jenis suntik lebih tinggi dibanding jenis kontrasepsi hormonal lainnya, seperti pil dan implant. Alat kontrasepsi suntik diminati, karena caranya paling mudah yaitu hanya menyuntikkan zat hormonal ke dalam tubuh dan akseptor tidak perlu berulang kali ke fasilitas pelayanan kesehatan (Zahroh and Isfandiari (2015), Sari Novalia (2015) dan Amran dan Damayanti (2018). Selain itu alat kontrasepsi suntik juga memiliki kemampuan yang efektif mencegah ovulasi, mengentalkan lendir serviks, menurunkan penetrasi sperma. Akan tetapi kontrasepsi mempunyai efek samping seperti kenaikan berat badan penggunanya (Sari Novalia, 2015). Kontrasepsi suntik dapat menyebabkan kenaikan berat badan WUS, rata-rata mencapai $1,9 \mathrm{~kg}$ pada tahun pertama (Zahroh and Isfandiari (2015); Sari Novalia (2015) ; Rahayu (2018). Jenis PIL juga diminati, jika cara minum teratur sesuai aturan, maka pil efektif mencegah kehamilan (Kawulur et al., 2015). Akan tetapi banyak WUS yang menolak menggunakan pil, karena takut efek sampingnya seperti gangguan keseimbangan hormonal dalam tubuh wanita yang dapat memicu terjadinya hipertensi. Penyakit hipertensi dapat menyebabkan kematian (Pangaribuan and Lolong. 2015; Kawulur et al. 2015; Sari et al., 2018). Penggunaan kontrasepsi pil yang terlalu lama dapat menyebabkan kardiovaskuler dan stroke, myocardial infarction dan penyakit arteri perifer (Zahidah et al., 2017; Sari et al., 2018). Jenis kontrasepsi implant merupakan jenis kontrasepsi yang paling tidak disukai WUS, karena efek sampingnya menyebabkan perubahan periode menstruasi, peningkatan berat badan, timbulnya jerawat, sakit kepala dan nyeri payudara (Hakimah dan Cahyanti, 2015; Manurung, 2013). Jenis implant diminati di wilayah yang sulit akses fasilitas kesehatan khususnya didaerah terpencil (Amran dan Damayanti, 2018).

Salah satu program untuk mengontrol laju pertumbuhan penduduk dan menurunkan angka kematian ibu adalah program Keluarga Berencana (KB). Sasaran program KB diantaranya adalah peningkatan prevalensi pemakaian alat kontrasepsi (Contraseptive Produktif Rate/CPR) menjadi 65\%, penurunan PUS tidak mau punya anak, tetapi tidak mau menggunakan kontrasepsi dan peningkatan penggunaan Metode Kontrasepsi Jangka Panjang (MKJP) atau kontrasepsi hormonal menjadi 26,03\% Marlina (2017). Penggunaan kontrasepsi menurut usia reproduksi sehat dan muda lebih rendah dibanding kemampuan reproduksi tua, hal ini karena pada kemampuan reproduksi tersebut, WUS masih menginginkan menambah jumlah anak, maka jika pada usia seperti ini tidak dikendalikan, akan menyebabkan ledakan bayi atau baby boom (Manurung, 2013).

Faktor umur menurut hasil uji korelasi bivariat mempunyai hubungan yang signifikan $P=0,00<$ $\alpha(5 \%)$, terhadap pemilihan kontrasepsi hormonal. Hal ini sejalan dengan hasil penelitian Lontaan dan Dompas (2014), yang menyebutkan, bahwa umur memiliki hubungan dengan pemakaian kontrasepsi, karena umur berperan sebagai faktor intrinsik, seperti berhubungan dengan sistem hormonal seorang wanita. Jika tidak dikendalikan pada umur reproduksi muda, maka akan terjadi peningkatan laju pertumbuhan penduduk.

Tempat tinggal WUS menunjukkan hubungan yang signifikan $P=0,00<\alpha(5 \%)$, dengan pemanfaatan jenis kontrasepsi hormonal. Wanita usia subur yang berada di pedesaan lebih banyak menggunakan alat kontrasepsi hormonal dibanding di perkotaan. Hal ini disebabkan, karena wanita di desa ingin alat kontrasepsi yang praktis dan tidak berulang kali datang ke fasilitas pelayanan kesehatan untuk memperoleh pelayanan kontrasepsi. Selain itu kontrasepsi sangat efektif mencegah kehamilan, sehingga sangat baik untuk mengatur jarak kelahiran (Zahroh and Isfandiari. 2015; (Sari Novalia. 2015; Amran dan Damayanti. 2018)

Pendidikan WUS saat ini masih menjadi permasalahan dalam pemanfaatan kontrasepsi hormonal, untuk mencegah kehamilan. Menurut hasil penelitian Manurung (2013), bahwa dilihat dari pendidikan, konseling, dan konselor, sebanyak $60 \%$ responden tidak mengetahui model kontrasepsi yang benar, hanya sedikit wanita berpendidikan lebih tinggi mengetahui metode kontrasepsi yang digunakan. Pendidikan WUS menikah setelah dilakukan uji korelasi bivariat menunjukkan tidak ada hubungan nilai $P=0,40>\alpha(5 \%)$, dengan pemanfaatan 
kontrasepsi hormonal. Hal ini sejalan dengan hasil penelitian Pramono dan Ulfa (2011) dalam Lontaan dan Dompas (2014), menyatakan bahwa tidak ada hubungan antara tingkat pendidikan dengan pemilihan kontrasepsi.

Menurut hasil penelitian Amran dan Damayanti (2018), bahwa wanita yang memiliki dua atau lebih anak yang masih hidup, keinginan untuk membatasi kelahiran jadi meningkat, sehingga memicu kebutuhan kontrasepsi meningkat. Hasil analisis korelasi bivariat menunjukkan ada hubungan yang signifikan $\mathrm{P}=0,00<\alpha(5 \%)$ antara jumlah anak yang dimiliki WUS dengan pemanfaatan jenis kontrasepsi hormonal yang dipilih dan digunakan WUS menikah. Ibu yang mempunyai anak ideal (1-2 orang anak) lebih banyak menggunakan kontrasepsi suntik $45,2 \%$, sementara penggunaan kontrasepsi suntik terendah terdapat pada keluarga yang memiliki anak lebih dari 6 sebanyak $0,8 \%$. Hal ini sejalan dengan hasil penelitian sebelumnya oleh Angoi (2012) dalam Lontaan dan Dompas (2014) menyatakan bahwa ada hubungan yang signifikan antara paritas (jumlah anak) dengan pemilihan kontrasepsi. Menurut Yunianti (2010) dalam Pinontoan et al. (2014) menyebutkan paritas merupakan faktor yang paling dominan yang mempengaruhi rendahnya cakupan kontrasepsi. Menurut beberapa peneliti Suandi (2010) dan Hartoyo (2011) dalam Saskara DGA dan Marhaeni NIA (2015), bahwa keikutsertaan ber KB akan terjadi ketika jumlah anak yang lahir hidup melebihi atau sama dengan jumlah anak yang diinginkan keluarga. Alwin dan Ketut (2012) serta Palamuleni (2013) dalam Saskara DGA dan Marhaeni NIA (2015) juga menyatakan jumlah anak merupakan salah satu faktor yang paling berpengaruh dalam penggunaan kontrasepsi.

Secara ekonomi, bahwa WUS yang bekerja bermanfaat untuk perbaikan ekonomi keluarga dan sekaligus perbaikan pembiayaan kesehatan termasuk pembiayaan kontrasepsi hormonal yang diminati. Pekerjaan wanita memiliki pengaruh terhadap fertilitas dan penggunaan kontrasepsi. Kontrasepsi bagi wanita pekerja, sangat berguna untuk mengatur dan membatasi kelahiran dalam mendukung karier kerja khususnya bagi wanita yang bekerja diluar rumah sebagai karyawati yang diupah dan saat ini WUS karyawati cenderung memiliki anak sedikit di banding yang tidak bekerja (Saskara DGA dan Marhaeni NIA. 2015). Hasil analisis statistik pada penelitian ini juga menunjukkan ada hubungan signifikan $\mathrm{P} 0,00<\alpha(5 \%)$ antara pekerjaan dengan pemilihan pemanfaatan kontrasepsi hormonal. Hal ini sejalan dengan hasil penelitian Marlina (2017) dan Andriana dan Amami (2018), bahwa ada hubungan signifikan antara pekerjaan dengan penggunaan kontrasepsi hormonal jenis implant dan ada hubungan biaya dengan penggunaan implant. Pentingnya WUS bekerja dalam mendukung pendapatan keluarga dan keikutsertaan kontrasepsi hormonal, menurut Okech, et al (2011) dalam Saskara DGA dan Marhaeni NIA (2015), ketiadaan sumber pendapatan akan menyebabkan penurunan penggunaan pelayanan family planning seperti alat kontrasepsi dan pendapatan rumah tangga menunjukkan pengaruh positif terhadap lama penggunaan kontrasepsi

Efektivitas penggunaan kontrasepsi hormonal dalam program KB di Indonesia, sudah terbukti dan menunjukkan kemajuan, yang ditandai dengan semakin banyak masyarakat khususnya WUS menikah yang menggunakannya, tidak hanya di perkotaan tapi juga di perdesaan bahkan didaerah terpencil, baik yang berpenghasilan tinggi maupun rendah dan yang berpendidikan tinggi maupun rendah. Manfaat menggunakan alat kontrasepsi sudah dirasakan masyarakat sebagai langkah tepat untuk mewujudkan keluarga kecil bahagia dan sejahtera dan ditandai semakin banyak yang memiliki jumlah anak antara 1-2, khususnya wanita yang bekerja membantu suami mencari nafkah. Hal ini menunjukkan keberhasilan pelaksanaan program KB di Indonesia dan atas prestasi itu, maka Program KB di Indonesia ditetapkan sebagai salah satu "center of excellence" di bidang kependudukan dan keluarga berencana dan menjadi salah satu model success story pelaksanaan keluarga berencana di negara berkembang yang banyak ditiru oleh negara-negara berkembang di dunia. Saskara DGA dan Marhaeni NIA (2015)

\section{KESIMPULAN DAN SARAN}

\section{Kesimpulan}

Setelah dilakukan analisis dengan menggunakan uji korelasi bivariat, hasilnya menunjukkan terdapat beberapa faktor seperti kemampuan reproduksi, lokasi tempat tinggal, kepemilikan jumlah anak dan pekerjaan WUS menikah yang mempunyai hubungan signifikan dengan penggunaan kontrasepsi hormonal, akan tetapi faktor pendidikan menunjukkan tidak ada hubungan dengan penggunaan kontrasepsi hormonal. 


\section{Saran}

Berdasarkan penelitian diatas, disarankan WUS lebih baik menggunakan kontrasepsi suntik, karenan kontrasepsi suntik selain efektif mencegah kehamilan, juga mudah pemasangannya dan memiliki efek samping yang lebih ringan dari pada pil dan implant. Selain itu petugas kesehatan sebaiknya memberikan informasi yang benar kepada semua WUS menikah yang ingin menggunakan kontrasepsi hormonal, agar mereka dapat mengetahui efektivitas kemanfaatan dan besarnya efek samping setiap jenis kontrasepsi hormonal, berdasarkan pertimbangan umur, jumlah anak yang dimiliki, lokasi tempat tinggal dan pekerjaan mereka.

\section{UCAPAN TERIMA KASIH}

Pada kesempatan ini tim penulis artikel mengucapkan terima kasih kepada Kepala Pusat Humaniora dan Manajemen Kesehatan dan Kepala seksi Latbang BKKBN Perwakilan Provinsi Jawa Timur dan tim data BKKB Provinsi Jawa Timur serta pengelola perpustakaan Pusat Humaniora dan Manajermen Kesehatan, yang sudah membantu dan memfasilitasi tim peneliti kami dalam melakukan analisis data dan penulisan artikel ini.

\section{DAFTAR PUSTAKA}

Amran, Y., Damayanti, R., 2018. Hubungan Antara Motivasi Keluarga Berencana Dan Persepsi Terhadap Alat Kontrasepsi Dengan Pola Penggantian Metode Kontrasepsi Di Nusa Tenggara Barat. Jurnal Kesehatan Reproduksi, 9 (1), 59-67.

Andriana, Amami, S., 2018. Hubungan Pendidikan dan Pekerjaan Akseptor KB Terhadap Pemakaian Kontrasepsi Implant di Puskesmas Rambah Samo If, in: Seminar Nasional. Presented at the Seminar Nasional, Universitas Pasir Pengaraian, Universitas Pasir Pengaraian, pp. 443-449.

Bernadus, J.D., Madianung, A., Masi, G., 2013. 1. Faktor-Faktor yang Berhubungan Dengan Pemilihan Alat Kontrasepsi Dalam Rahim (AKDR) Bagi Akseptor KB di Puskesmas Jailolo. Jurnal e-NERS (eNS), 1 (1), 1-10.

Hakimah, A., Cahyanti, R.D., 2015. Pengaruh Penggunaan Implant Satu Batang (Etonogestrel 68mg) Terhadap Gangguan Menstruasi Pada Peserta Metode Kontrasepsi Jangka Panjang Di Semarang. Media Medika Muda, 4, 485-490.

Handayani, L., Hariastuti, I., Latifah, C., 2012. Peningkatan Informasi Tentang Kb: Hak Kesehatan Reproduksi Yang Perlu Diperhatikan Oleh Program Pelayanan
Keluarga Berencana. Buletin Penelitian Sistem Kesehatan, 15 (3), 289-297.

Kawulur, L., Kundre, R., Onibala, F., 2015. Gambaran Pengunaan Pil KB Pada Wanita Usia Subur Dengan Hipertensi Diwilayah Kerja Puskesmas Tanawangko Kecamatan Tombariri. ejournal keperaweatan (e-Kp), 3 (3), 1-5.

Lontaan, A., Dompas, R., 2014. Faktor - Faktor Yang Berhubungan Dengan Pemilihan Kontrasepsi Pasangan Usia Subur Di Puskesmas Damau Kabupaten Talaud. Jurnal IImiah Bidan (Jldan), 2, 27-32.

Manurung, S., 2013. Model Pengambilan Keputusan Meningkatkan Akseptor Keluarga Berencana Metode Kontrasepsi Jangka Panjang. Kesmas: National Public Health Journal, 7, 483-488. tersedia pada: https://doi.org/10.21109/kesmas.v7i11.360.

Marlina, 2017. Analisis faktor yang berhubungan dengan penggunaan implant oleh akseptor KB Di puskesmas rawat inap sukabumi Kota bandar lampung. Jurnal Kesehatan, VIII, 69-77.

Pangaribuan, L., Lolong, D.B., 2015. Hubungan Penggunaan Kontrasepsi Pil dengan Kejadian Hipertensi Pada Wanita Usia 15-49 Tahun di Indonesia Tahun 2013 (Analisis Data Riskesdas 2013). Media Penelitian dan Pengembangan Kesehatan, 25, 1-8. Tersedia pada: https://doi.org/10.22435/mpk.v25i2.4233.89-96

Pinontoan, S., Solang, S.D., Tombokan, S.G.J., 2014. FaktorFaktor Yang Berhubungan Dengan Penggunaan Alat Kontrasepsi Dalam Rahim Di Puskesmas Tatelu Kabupaten Minahasa Utara. Jurnal IImiah Bidan (Jldan), 2, 17-23.

Pratiwi, D., Syahredi, Erkadius, 2014. Hubungan Antara Penggunaan Kontrasepsi Hormonal Suntik DMPA dengan Peningkatan Berat Badan di Puskesmas Lapai Kota Padang. Jurnal; Kesehatan Andalas, 3 (3), 365-369.

Purwaningsih S, S., 2012. Desentralisasi Program Keluarga Berencana: Tantangan dan Persoalan Kasus Provinsi Kalimantan Barat. Jurnal Kependudukan Indonesia, VII, 109-125.

Rahayu, S., 2018. Efek Samping Kontrasepsi Suntik Cyclofem Dan DMPA. babul IImi_Jurnal IImiah Multi Science Kesehatan, 9 (3), 314-322.

Sari, A.P., Yerizel, E., Serudji, J., 2018. Perbedaan Kadar Aldosteron dan Tekanan Darah pada Akseptor KB Pil Kombinasi Berdasarkan Lama Pemakaian Kontrasepsi. Jurnal Kesehatan Andalas, 7, 6.

Sari Novalia, I.R., 2015. Kontrasepsi Hormonal Suntik Depo Medroxyprogesterone Acetate (DMPA) sebagai Salah Satu Penyebab Kenaikan Berat Badanatna Novalia Sari.pdf. Majoriti, 7 (2), 67-72.

Saskara DGA, I., Marhaeni NIA, A., 2015. Pengaruh Faktor Sosial, Ekonomi, dan Demografi Terhadap Penggunaan Kontrasepsi di Denpasar. Jurnal Ekonomi Kuantitatif Terapan, 8, 155-161. 
Schoemaker, J., 2005. Contraceptive Use Among the Poor in Indonesia. Int. Fam. Plan. Perspect. 31, 106-114. Tersedia pada: https://doi.org/10.1363/3110605

Sriwahyuni, E., Wahyuni, C.U., 2012. Hubungan antara Jenis dan Lama Pemakaian

Alat Kontrasepsi Hormonal dengan Peningkatan Berat Badan Akseptor. Indonesian Journal of Public Health,8 (3), 112-116.

Sumantri, A.W., 2018. Hubungan Suntikan KB 3 Bulan Dengan Kenaikan Berat Badan Di Desa Laya Wilayah Kerja Uptd Puskesmas Tanjung Agung Kecamatan Baturaja Barat Tahun 2018. babul IImi jJurnal IImiah Multi Science Kesehatan, 8, 121-128.
Ujiani, S., 2005. Hubungan Antara Usia dan Jenis Kelamin dengan Kadar Kolesterol Penderita Obesitas RSUD Abdul Moeloek Provinsi Lampung. jurnal Kesehatan, VI (1), 43-48.

Zahidah, A.K., Udiyono, A., Adi, M.S., 2017. Gambaran Faktor-Faktor Tekanan Darah Pada Akseptor KB Hormonal Di Wilayah Kerja Puskesmas Kedungmundu 2016. Jurnal Kesehatan Masyaraka, 5, 174-179.

Zahroh, A.H., Isfandiari, M.A., 2015. Pengaruh Gaya Hidup Terhadap Perubahan Indeks Masa Tubuh Pada Akseptor Kontrasepsi Hormonal Suntik Tiga Bulan. Jurnal berkala epidemiologi, 3 (2), 170-180. 